\title{
Vasculitis of small and large vessels, a casual association?
}

\author{
Filipa Pedro' \\ Yahia Abuowda ${ }^{1}$ \\ Nuno Craveiro ${ }^{1}$ \\ Ana Alves Oliveira ${ }^{1}$ \\ Ana Mestre 1 \\ Cristina Santos ${ }^{1}$
}

1. Internal Medicine Department - III, District Hospital of Santarém, Portugal

\section{SUMMARY}

The authors report a case of a 69-year-old man with idiopathic leukocytoclastic cutaneous vasculitis. For three years, the lesions recurred with progressive worsening and were associated with systemic manifestations of low-grade fever, weight loss and raised inflammatory markers. The patient latter presented a 6th cranial nerve involvement, raising the concern of a possible systemic vasculitis, which was latter evidenced by the development of deep vein thrombosis and angina pectoris. The treatment of the patient witch based on the decreasing of inflammatory activity, by using effective immunosuppressive therapy, with lower toxicity is more important than identifying the type of the vasculitis. This case illustrates the importance of awareness for the systemic involvement that can occur in up to $50 \%$ of patients with leukocytoclastic cutaneous vasculitis.

KEYWORDS: Vasculitis. Vasculitis, leukocytoclastic, cutaneous. Giant cell arteritis.

\section{INTRODUCTION}

Cutaneous leukocytoclastic vasculitis (VLC) is a common vasculitis in the clinic with no predilection for sex, manifesting in a broad spectrum of ages $\mathbf{1}^{1,2}$. The lesions can assume several characteristics nodular, vesicular, bullous or even ulcerated, with dimensions ranging from millimetres to several centimetres. They may be pink or purpuric ${ }^{3}$. Its physiopathology rests on the immune response to invasion by endogenous or exogenous antigens, and the type III reaction of Gel and Coombs is implicated in its pathogenesis.

In order to differentiate from other vasculitis, histologically the dermal lesions will have to present at least two of the three required criteria: presence of perivascular leukocyte infiltrate (neutrophils in the early lesions and lymphocytes in the late phase); vascular destruction with extravasation of blood elements and fibrinoid necrosis ${ }^{4}$.

In most cases, VLC occurs in isolation and it is not always possible to clarify its origin. However, in about $50 \%$ of cases it is associated with systemic vasculitis. The study of series of patients with greater numerical expressiveness allowed us to conclude that this association is especially common if VLC is late onset (after 65 years old), recurs within a month and is accompanied by neurological manifestations ${ }^{5,6}$.

VLC also appears to be associated with drug re- 
actions, infections (HIV), connective tissue diseases and neoplasia.

The 2012 Chapel Hill Consensus Conference on vasculitis highlights that there are two entities with different prognoses - leukocytoclastic vasculitis of an isolated organ with a benign and self-limiting course and that related to systemic diseases, which has a less favourable outcome ${ }^{6}$. Treatment is based on the use of oral corticosteroid therapy for 4-6 weeks, with progressive dose reduction later. If symptoms recur, other drugs, such as azathioprine or methotrexate, may be associated ${ }^{7}$.

Temporal arteritis is a vasculitis of large and medium calibre vessels of granulomatous character that preferentially reaches the vessels above the diaphragm and especially the intracranial vessels. There are few references to occasionally monitor about small vessel vasculitis, as is the case for IgA vasculitis, systemic lupus erythematosus, rheumatoid arthritis, and Sjögren's Syndrome ${ }^{6}$. The inflammatory process begins in the adventitia of the vessel after stimulation of the $\mathrm{T}$ lymphocytes that trigger the production of interleukin 17 and interferon gamma. These, in turn, lead to an increase in angiogenesis and proliferation of myofibroblasts, culminating in intimal proliferation ${ }^{8}$. Therapy of temporal arteritis is fundamentally based on corticotherapy. In relapses, immunosuppression is used with a variable success percentage ${ }^{9}$.

\section{CLINICAL CASE}

A 69-year-old man, a retired locksmith, is admitted to a medical ward for the first time in 2012 reporting two months of fever, asthenia, arthralgia, loss of about $5 \mathrm{~kg}$, and nodular erythematous lesions of 3 mm of diameter, slightly itchy, spread throughout his torso. He said that these lesions lasted for several months, appearing and disappearing, giving rise to hyperpigmented zones. Of pathological antecedents to be mentioned, only hypothyroidism and dyslipidaemia, being medicated with levothyroxine and fenofibrate. At the objective examination, the patient had a good general condition, well hydrated, ruddy, feverish (atrial temperature of $38^{\circ} \mathrm{C}$ ), normotensive, with no signs of poor peripheral perfusion and with symmetrical and large pulses. Cardiopulmonary auscultation showed no alterations. He had no adenomegaly or organomegaly. The wrist and knee mobilization was painful, but no actual signs of arthritis.
It was verified the presence of erythematous-nodular lesions with about $3 \mathrm{~mm}$ of diameter spread throughout the torso, as well as hyperpigmented macular lesions of smaller diameter. There were no lesions on the palms or plants. Analytically, it should be highlighted the elevation of the inflammatory parameters with sedimentation rate (SV) of $100 \mathrm{~mm}$ in the first hour and C-reactive protein (CRP) of $19 \mathrm{mg} / \mathrm{dL}$, elevated ferritin $(446.5 \mathrm{ng} / \mathrm{dL})$ and slightly elevated alpha 2 globulin. Coagulation (APTT and prothrombin time), renal function, urinalysis and hepatic enzyme without changes. Normal immunoelectrophoresis. Negative cryoglobulinemia screening. Negative tumour markers (CA 19.9, CA 125, CEA, PSA and beta-2 microglobulin). Complement without alterations, anti-nuclear antibodies (ANA) and negative neutrophil anti-cytoplasmic antibodies (Anca). Normal angiotensin converting enzyme. Negative blood and urine cultures. Serologies for HIV, HCV, HBV and syphilis negative. Imaging tests (chest x-ray and thoracic-abdominal-pelvic CT) did not identify any lesions.

Echocardiogram with good systolic function and no valvular vegetation. Normal upper digestive endoscopy and colonoscopy, and normal positron emission tomography.

He initiated non-steroidal anti-inflammatory therapy (naproxen $500 \mathrm{mg} 3$ times/day), with fever and arthralgia disappearing and inflammatory parameters decreasing considerably.

He was submitted to skin biopsy, which revealed inflammatory infiltrate and fibrinoid necrosis (Figure 1), allowing the diagnosis of leukocytoclastic vasculitis. He was discharged with an indication for follow-up at a medical appointment.

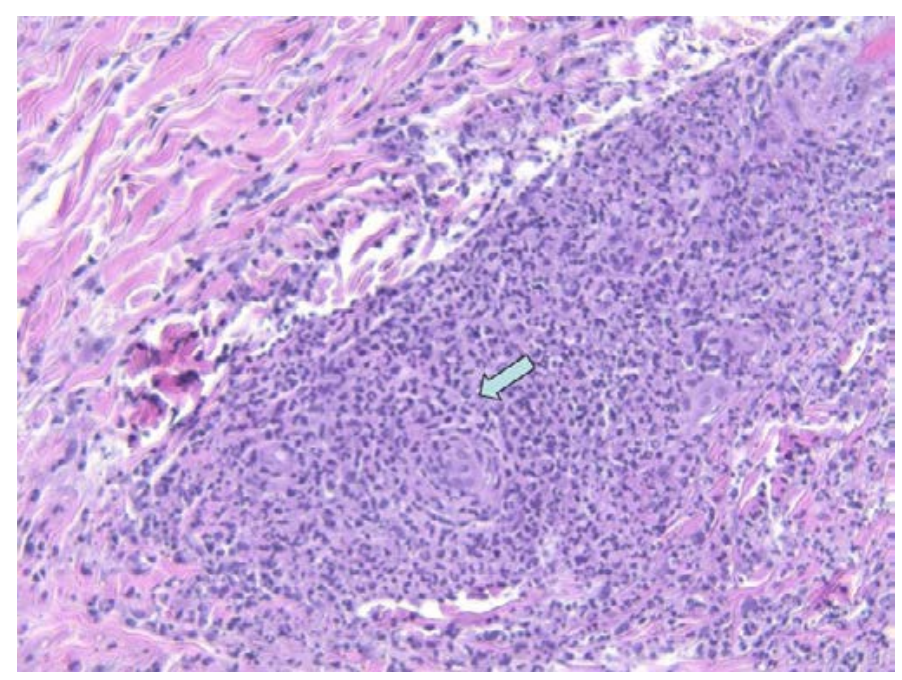

FIGURE 1. 
About five months later, the patient was readmitted for sudden diplopia by paresis of sixth left cranial pair, generalized fatigue and asthenia. He denied headache or loss of visual acuity. The analysis revealed normal normocytic anaemia (haemoglobin $9 \mathrm{~g} / \mathrm{dL}$ ), high SV (130 $\mathrm{mm}$ in the first hour) and 24-hour proteinuria in the subnephrotic $(1,200$ $\mathrm{g} / \mathrm{dL})$. The remaining study was negative: Anas, Ancas, antiphospholipid antibodies, cytochemical and bacteriological examination of the cerebrospinal fluid (CSF), serologies for Borrelia, herpes virus and Echovirus (blood and CSF), CSF oligoclonal bands test. The MEF gene of the family fever was negative. Cranioencephalic CT, cerebral magnetic resonance angiography and cervical echo-Doppler without changes. Renal ultrasonography did not identify asymmetries in the size of the kidneys, which presented normal cortical-medullar differentiation. The echo-Doppler and magnetic resonance angiography of the renal vessels revealed no alterations. Renal biopsy was normal and did not reveal changes suggestive of vasculitis. Electromyogram of limbs normal. Given the context of the first hospitalization, and after the exhaustive study excluding other aetiologies, this condition was attributed to probable vasculitis of the vasa nervorum of the sixth cranial pair. He started low dose corticosteroid therapy (30 mg prednisolone day), with total normalization of inflammatory parameters and recovery of ocular movements.

He maintained ambulatory corticosteroid therapy at a dose ranging from $10 \mathrm{mg}$ to $17.5 \mathrm{mg}$. However, in mid-2013, he started complaints of typical angina again. He underwent an exercise test that proved to be positive and was then submitted to cardiac catheterization, which did not demonstrate occlusive coronary lesions. Once again, it was hypothesized that this is a vasculitis manifestation. The control of dyslipidaemia was intensified and antiplatelet and beta-blocker therapy (nebivolol) was initiated. It was clear that the reappearance of these systemic complaints coincided with the attempt to decrease the dose of corticosteroids. Thus, azathioprine was started as a corticosteroid sparer, but it was not able to lower the dose of prednisolone beyond $17.5 \mathrm{mg}$ without reappearance of symptoms. Methotrexate therapy was then chosen at $15 \mathrm{mg}$ weekly and folic acid $5 \mathrm{mg}$, with which it had good symptomatic control. However, he had to interrupt due to infectious complication of hepatic abscess. In two more occasions, skin lesions reappeared, biopsies were performed, and the diagnosis of leukocytoclastic vasculitis was again concluded.

In January 2015 he suffered left iliofemoral thrombosis, treated with enoxaparin at a therapeutic dose (1 mg/kg of body weight).

In 2016, he started complaining of lameness of the right leg and pain in the twin region, and critical ischemia at the femoral level was diagnosed. He did a thromboendarterectomy successfully, being later medicated with rivaroxaban.

A few months later, he developed right temporal headache of intense character, fulfilling the clinical criteria for the diagnosis of temporal arteritis, for which he was submitted to biopsy of the temporal artery. This revealed intimal thickening and fibrosis, with focal fragmentation of the internal elastic lamina, without observation of granulomas, giant cells and/or inflammatory infiltrate of the vessel wall - aspects that may correspond to treated temporal arteritis.

At the moment he is preparing to initiate immunosuppressive therapy with mycophenolate mofetil, since he maintains the need for high doses of steroids. This therapy was not started earlier due to the occurrence of a femoral neck fracture after a fall, followed by pneumonia and a long period of motor rehabilitation.

\section{DISCUSSION}

In the case presented, at the first hospital stay the patient had palpable, hardened and painful skin lesions. After exclusion of infections, medication and other pathologies, either autoimmune or neoplastic, the diagnosis of idiopathic VLC was confirmed by skin biopsy. However, after a few months, the patient is hospitalized for systemic complaints and for a six-pair cranial monoparesis. After exclusion of embolic and/or neoplastic aetiology, the exclusion of a vasculitis with central involvement became preponderant. Vasculitis that may involve the CNS are Wegener's granulomatosis, polyarteritis nodosa, and microscopic polyangiitis. This effect may be due to direct nerve injury, to the appearance of granulomas in the vicinity of the nerve, or to the vasculitis of the vasa nervorum ${ }^{5}$. The cranial nerves most affected by vasculitis phenomena are the fifth, sixth and seventh pairs ${ }^{10}$. In the case presented, the patient did not present respiratory symptoms 
or blood pressure changes. Eosinophilia and the presence of neutrophil anti-cytoplasmic antibodies were not registered. Serologies remained negative. The subnephrotic proteinuria that he presented remained unprovoked, since a renal biopsy was performed, which did not detect the presence of complement, immunoglobulin deposits and/or amyloid deposits. These aetiologies were then excluded, with the hypothesis of open systemic vasculitis being maintained.

In 2013, the patient had an episode of angina. Despite positive exertion evidence, catheterization did not reveal changes. The hypothesis of systemic vasculitis of medium and large vessels is again considered, since no stenotic lesions were seen at the level of the coronary arteries. The vasculitis that frequently present with coronary involvement are Wegener's granulomatosis and Kawasaki's disease, both excluded in the diagnostic investigation. In addition, temporal arteritis reaches the aorta and the supra-aortic trunk. All of the remaining vasculitis induces arrhythmias due to damage to the cardiac or myocardial conduction system, and does not reach the coronary vessels".

During the etiological investigation, the patient presented several intercurrences. Deep venous thrombosis and, subsequently, acute ischemia of the right lower limb occurred during a period of elevation of the inflammatory parameters coincident with the reduction of corticotherapy dose. In the literature, there is evidence of increased thrombotic risk in vasculitis, predominantly in those with positive Ancas, which was again excluded in this patient ${ }^{12}$.

The development of right temporal headache, with clinic and histology compatible with temporal arteritis, allowed us to conclude that all vascular manifestations present would be related to this type of vasculitis. Giant cell vasculitis or temporal arteritis is a granulomatous vasculitis of large and medium-sized vessels and affects, for the most part, cases of adults over 50 years of age. It preferably involves the extracranial branches of the carotid arteries, such as the temporal artery ${ }^{9}$. The typical symptom of this type of vasculitis is headache, located in the temporal region. Other symptoms include fever, malaise, anorexia, myalgia, and claudication of the jaw, sensitivity of the scalp, diplopia and ptosis. The most feared complication is unilateral/bilateral vision loss due to ischemic optic nerve neuropathy. The aorta and its branches may also be involved in this type of vasculitis, with risk of rupture and/or dissection. Symptoms of polymyalgia rheumatica may coexist ${ }^{1,5}$. Although involving the carotid arteries and their branches, the frequency of strokes in these patients is low ${ }^{13}$. There have been reports of acute atrophy, both of the vessels of the upper limbs and vessels of the lower limbs ${ }^{14}$. The diagnosis of temporal arteritis should take into account all clinical and laboratory assessment, and should not rely solely on biopsy, which may be positive in a small number of cases. Diagnostic criteria are five: age equal to or greater than 50 years old, severe headache, elevated sedimentation rate (SV), temporal artery engorgement and compatible biopsy. It suffices to present three of the five previous criteria for the diagnosis ${ }^{15}$. In the presented case, the diagnosis was made possible by the clinical and analytical evaluation, since the patient is 74 years old, presented severe headache and high SV. The biopsy of the temporal artery was suggestive, presenting features of treated temporal arteritis. This was due to the long-term corticosteroid therapy that the patient performed since the diagnosis of idiopathic leukocytoclastic vasculitis.

Future therapy should be sufficiently effective and safe in order to avoid further recurrences. He will go through, within the current contingencies, the use of monoclonal antibodies or by immunosuppression with oral drugs that, nevertheless, allow a good control of vascular inflammation.

\section{CONCLUSION}

Vasculitis is a group of heterogeneous diseases, mostly difficult to diagnose. In many cases, only after several hospitalizations the final diagnosis is established, since they present a complex clinic, easily confused with other pathologies. In addition, the lack of a specific diagnostic test, in addition to the biopsy of the affected tissues, which is often not feasible, contributes to the delay in its early detection. Leukocytoclastic vasculitis is common in clinical practice and does not require, in general, specific therapy. Its recurrence, especially in age groups over 65 years, and CNS attainment may alert to the existence of associated disease. There is no association with temporal arteritis but with systemic lupus erythematosus and IgA vasculitis. 
This case may just be a fortuitous association.

At this time, it is important that the patient resume immunosuppressive therapy more effectively and with lower possible infectious risk, since we recognize that the disease still maintains activity, despite apparent symptomatic control under corticosteroid therapy.

\section{Conflicts of interest}

The authors declared no conflict of interest.

\section{Acknowledgements}

We would like to express our appreciation for the work developed and for the precious help of Dr. João Aranha acting as dermatologist/anatomopathologist.

\section{RESUMO}

Os autores reportam um caso de vasculite leucocitoclástica recidivante num homem de 69 anos. Durante cerca de três anos as lesões cutâneas de vasculite leucocitoclástica reapareceram periodicamente, acompanhando-se sempre de um quadro sistêmico caracterizado por febrícula, perda de peso e astenia, assim como aumento de novo dos parâmetros inflamatórios. O aparecimento de parésia do sexto par craniano no decurso de uma dessas recorrências cutâneas levantou a hipótese de estarmos perante uma vasculite mais agressiva, com envolvimento extracutâneo. Esse envolvimento sistêmico foi novamente evidente com aparecimento de angina pectoris e trombose venosa profunda. Atualmente, mais do que a identificação do tipo de vasculite, a abordagem dos doentes com essa patologia assenta na cessação da atividade inflamatória recorrendo a terapêutica imunossupressora eficaz, com a menor toxicidade possível. Destacamos a importância da vigilância do componente sistêmico, que pode ocorrer até $50 \%$ na vasculite leucocitoclástica cutânea.

PALAVRAS-CHAVE: Vasculite. Vasculite leucocitoclástica cutânea. Arterite de células gigantes.

\section{REFERENCES}

1. Khasnis A, Langford CA. Update on vasculitis. J Allergy Clin Immunol 2009;123(6):1226-36.

2. Sharma AM, Singh S, Lewis JE. Diagnostic approach in patients with suspected vasculitis. Tech Vasc Interv Radiol. 2014;17(4):226-33.

3. Einhorn |, Levis |T. Dermatologic diagnosis: leukocytoclastic vasculitis. Perm J. 2015;19(3):77-8

4. Brandt HRC, Arnone M, Valente NYS, Criado PR, Sotto MN. Vasculite cutânea de pequenos vasos: etiologia, patogênese, classificação e critérios diagnósticos - Parte I. An Bras Dermatol. 2007;82(5):387-406.

5. Bougea A, Anagnostou E, Spandideas N, Triantafyllou N, Kararizou E. Atualização das manifestações neurológicas das vasculitis e das doenças do tecido conjuntivo: revisão de literatura. Einstein. 2015;13(4):627-35.

6. Bouiller K, Audia S, Devilliers H, Collet E, Aubriot MH, Leguy-Seguin V, et al. Etiologies and prognostic factors of leukocytoclastic vasculitis with skin involvement: a retrospective study in 112 patients. Medicine (Baltimore) 2016;95(28):e4238.

7. Meza-Ayala CM, Dehesa-López E, Ruelas-Perea AG, Peña-Martínez E. Vasculitis leucocitoclástica: un reto diagnóstico para el médico internista. Med Int Mex. 2015;31(1):113-8.

8. Kermani TA, Warrington K. Giant cell arteritis. In: Stanley JC, Veith F,
Wakefield TW, eds. Current therapy in vascular and endovascular surgery. $5^{\text {th }}$ ed. Philadelphia: Elsevier; 2014. p.10-2

9. Calvo-Romero J. Giant cell arteritis. Postgrad Med J. 2003;79(935):511-5.

10. Koike H, Sobue G. Clinicopathological features of neurophathy in anti-neutrophil cytoplasmic antibody-associated vasculitis. Clin Exp Nephrol 2013;17(5):683-5.

11. Dutschmann L, Ferreira C, Sousa G, Miranda MI, Santos MJ, Pereira MJ, et al. Manifestações cardíacas das das doenças do conectivo. Acta Medica Portuguesa. 1989; 2: 103 -110

12. Tomasson G, Monach PA, Merkel P. Thromboembolic disease in vasculitis. Curr Opin Reumathol. 2009;21(1):41-6.

13. González-Gay MA, Blanco R, Rodríguez-Valverde V, Martínez-Taboada VM, Delgado-Rodriguez M, Figueroa M, et al. Permanent visual loss and cerebrovascular accidents in giant cell arteritis: predictors and response to treatment. Arthritis Rheum. 1998;41(8):1497-504.

14. Assie $C$, Janvresse $A$, Plissonier $D$, Levesque $H$, Marie I. Long-term follow-up of upper and lower extremity vasculitis related to giant cell arteritis: a series of 36 patients.

15. Hunder GG, Bloch DA, Michel BA, Stevens MB, Arend WP, Calabrese LH, et al. The American College of Rheumatology 1990 criteria for the classification of giant cell arteritis. Arthritis Rheum. 1990;33(8):1122-8. 